\title{
The Croatian adaptation of the Multilingual Assessment Instrument for Narratives*
}

\author{
Gordana Hržica \\ University of Zagreb \\ Jelena Kuvač Kraljević \\ University of Zagreb
}

This paper presents the Croatian version of the Multilingual Assessment tool for Narratives (MAIN), outlines its development and describes the research that has used it to assess narrative skills in monolingual and bilingual speakers. The Croatian version of MAIN has so far been used in three research projects and results have been presented in five peer-reviewed articles (published or in press) covering a total of 175 children in the age range from 5;0 to 9;0 (20 with developmental language disorder) and 60 adults, age range from 22 to 76 . The accumulated results indicate that MAIN can differentiate narrative skills of speakers in distinct age groups and can distinguish children with language disorders form children with typical language development.

1 Introduction: the importance of narrative assessment as a part of language assessment in Croatia

Language assessment is a comprehensive process of collecting information about a speaker's language ability to enable speech and language pathologists and other experts to assess his or her language knowledge and competencies. Language assessment should be able to identify deficits in language acquisition and processing in monolingual and bilingual speakers, meaning that it must be based on standardized, validated procedures.

Since 2000, extensive efforts have been aimed at developing objective, validated tools for Croatian language assessment. Croatian versions of widely used tests of language comprehension, such as the Test of Receptive Grammar in Croatian (TROG-2:HR; Bishop et., al., 2013), and of language production, such as the New Reynell Developmental Language

\footnotetext{
* This work has been supported in part by Croatian Science Foundation under the project Multilevel approach to spoken discourse in language development (UIP-2017-05-6603).
} 
Scales in Croatian (NRDLS-HR; Edwards et al., 2019), have been developed. These tests assess the grammar and lexicon of monolingual Croatian speakers. In Croatian, there are no validated tools to assess discourse skills and pragmatic skills.

Narration is a higher-level language skill and a key pragmatic ability. Narrative assessment should thus be a crucial part of language and communication assessment in research and the clinic (Botting, 2002). Narrative assessments can be compared with results on standardized tests across age groups; it can contribute to differentiation between children without language disorders and children with different types of disorders, such as developmental language disorder, language disorders involving primarily pragmatic difficulties, and social communication disorder; and it can provide insights into writing skills. Therefore, appropriate narrative tools are needed for monolingual and bilingual Croatian speakers.

The Multilingual Assessment Instrument for Narratives (LITMUS-MAIN, hereafter MAIN; Gagarina et al. 2012, 2015, 2019), has shown to be effective and sensitive in distinguishing children with developmental language disorder form children with typical language development (Boerma et al., 2016; Tsimpli et al., 2016). It has also proven powerful for gaining linguistic and cognitive insights into narrative ability in English and in other languages by enabling analyses on microstructure and macrostructure (e.g. Gagarina et al. 2015, Bohnacker, 2015, Altman et al. 2015, Lindgren 2019).

\section{Developing MAIN for Croatian}

MAIN was developed within the Narrative and Discourse Working Group (WG2) of the COST Action IS0804 Language Impairment in a Multilingual Society: Linguistic Patterns and the Road to Assessment. It is part of a battery of tests known as the Language Impairment Testing in Multilingual Settings (LITMUS), all developed within the same COST Action. We were members of the Working Group during and after the COST Action. We worked with other members under the leadership of a core group to develop materials and pilot MAIN versions in other languages. When MAIN was first published, it was released in 26 language versions, including Croatian (Gagarina et al., 2012).

The Croatian version of MAIN is not a direct translation of the English instrument but an adaptation in the true sense of the word, because it tries to take into consideration the linguistic properties of instructions, story scripts, questions, and answers. The Croatian team in WG2 worked together on the adaptation, continuously assessing the alignment between the original and Croatian versions in terms of the following four areas (Borsa et al., 2012, p. 425): (1) semantic equivalence, which involves assessing whether the words have the same meaning, whether items have more than one meaning, and whether the translation contains grammatical errors; (2) idiomatic equivalence, which involves assessing whether the translation of the items altered their cultural meaning; (3) experiential equivalence, which involves assessing whether a particular item is applicable in the new culture and, if not, replacing it with an equivalent item; 
and (4) conceptual equivalence, which involves assessing whether a given term or expression, even if properly translated, assesses the same aspect in different cultures.

The Croatian team spent additional time coming up with appropriate, common nouns for characters in the stories, since they could not be directly translated, and for translating the instructions for each of the four stories. Multiple examples of possible responses of respondents were included.

The first MAIN manual (Gagarina et al. 2012) included preliminary results for 40 monolingual children, half with typical language development and half with developmental language disorder. These results were reported at COST meetings and workshops. An updated version of MAIN and the English version of the manual was released in 2019 (Gagarina et al. 2019). It incorporated various changes, correction of minor errors and clarifications in some instructions and tables. This was the base for a new revised Croatian version (2020).

\section{Using the Croatian MAIN}

Since the release of the original Croatian version of MAIN in 2012, it has been used in several studies involving monolingual children with or without developmental language disorder and typically-developing bilingual children, carried out within the following three projects: "Adult Language Processing", funded by the Croatian Science Foundation (HRZZ-UIP-2013-112421) and lasting from 2014 to 2017; "Language Dominance of Bilingual Speakers Perceived as Balanced" (LADOBI), co-funded by the Marie Curie Action "Piscopia" and Framework 7 and lasting from 2014 to 2015; and the ongoing "Multilevel Approach to Spoken Discourse in Language Development", funded since 2018 by the Croatian Science Foundation (HRZZ-UIP2017-05-6603). Results from some studies within these projects have been published, others have been accepted by journals, while others are being drafted for submission.

\subsection{Projects in which the Croatian MAIN is part of the test battery}

\subsubsection{Adult Language Processing}

The "Adult Language Processing" project addressed psycholinguistic and neurolinguistic aspects of adults and elderly in Croatia. The project enrolled speakers with typical language status and patients with aphasia, dementia and dyslexia. This project showed that the narrative abilities of adult speakers with typical language status do not reach the maximum score (max = 17 points) on the MAIN tasks, and that they scored similarly on both stories (Figure 1). 


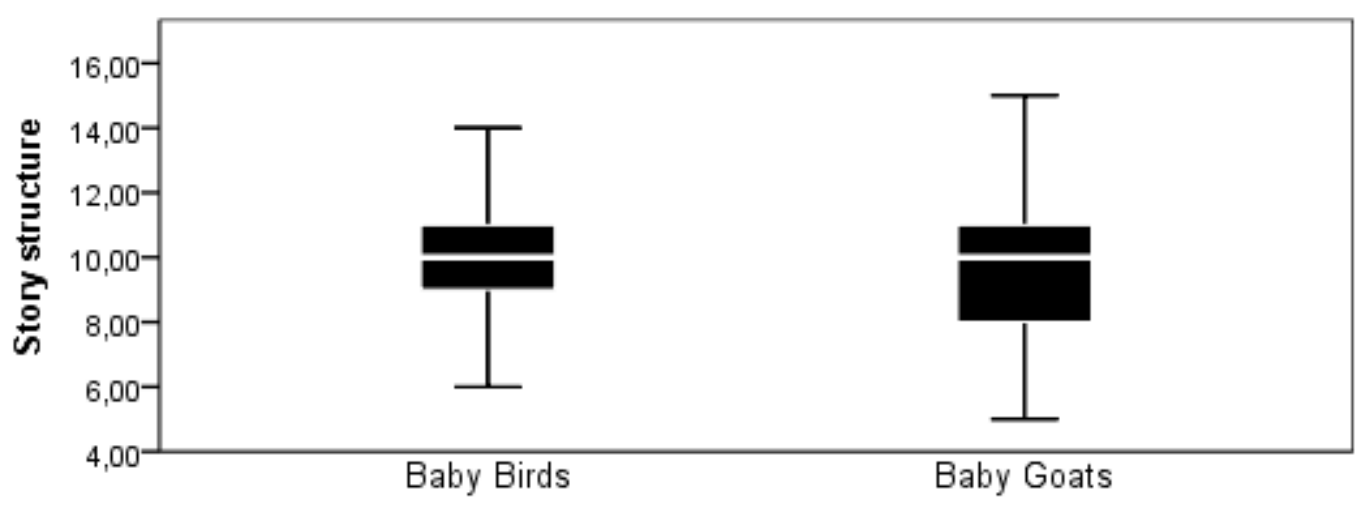

Figure 1: Median scores on the MAIN stories "Baby Goats" $(\mathrm{N}=30)$ and "Baby Birds" $(\mathrm{N}=30)$ for adult speakers of Croatian with typical language status.

\subsubsection{Language Dominance of Bilingual Speakers Perceived as Balanced}

Measuring and controlling for language dominance is crucial in research, but also holds psychological and societal importance because of its connections with language attrition and language loss (for an overview, see Köpke and Genevska-Hanke 2018). This project aimed to (1) measure language dominance in bilingual speakers of Italian and Croatian who were perceived as balanced, and (2) identify psychological and sociological factors relevant for determining language dominance. To build a complete linguistic profile of each speaker, their language production and comprehension were assessed using a range of linguistic tools, including MAIN. The results were compared to those obtained on standardized language tests of the two languages. When comparing two languages of the child (Figure 2), there is no significant difference between two groups, although median scores are better for the narratives in Croatian $(\mathrm{U}=744,5, \mathrm{p}=0.69)$.

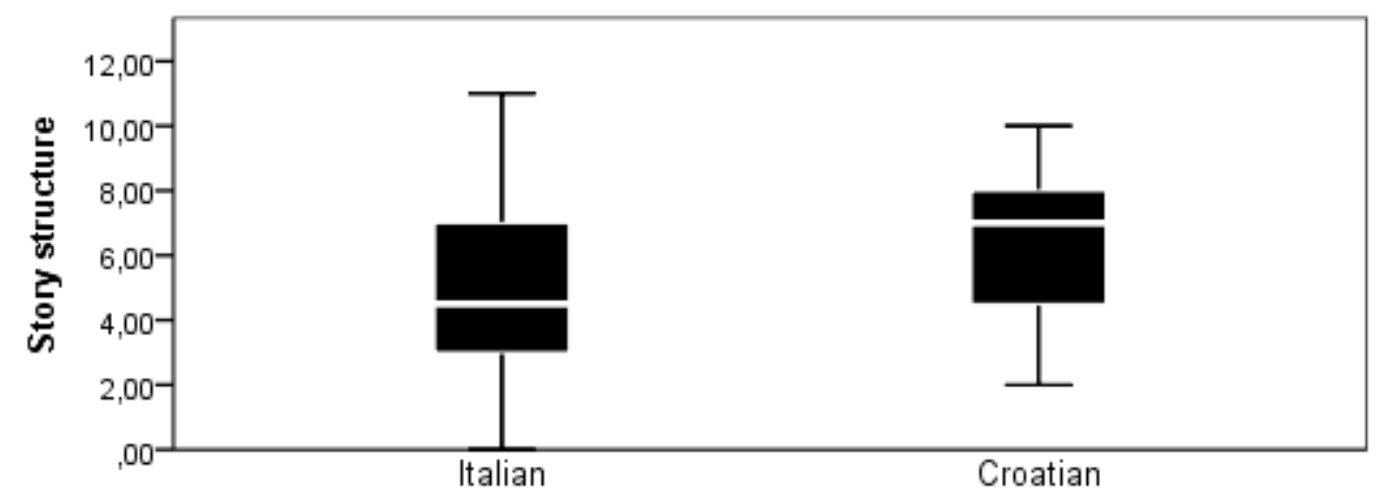

Figure 2: Median macrostructure scores for bilingual speakers of Croatian and Italian $(\mathrm{N}=30)$ when generating narratives in each of their languages.

\subsubsection{Multilevel Approach to Spoken Discourse in Language Development}

Discourse analysis is useful for assessing language knowledge (Botting, 2002), especially in bilingual speakers and speakers with language impairment (e.g. Hržica, Košutar \& Kramarić, 2019). Theories and approaches to understanding the structure of narrative discourse and its changes during language development have been primarily based on English, so they must be 
validated in typologically different languages. Studies of Croatian narrative discourse suggest that measures of microstructure have to be re-examined before being used in another language and that relevant discourse elements have to be observed within the perspective of Croatian language (Arapović et al., 2010; Gabaj \& Kuvač Kraljević, 2019; Hržica \& Lice, 2012; Kelić et al., 2012; Kuvač, 2004; Trtanj \& Kuvač Kraljević, 2017; Trtanj 2019). This project aims to (1) provide reliable insights into the cognitive and linguistic aspects of discourse formation, and (2) contribute to theoretical approaches to narrative discourse from a cross-linguistic perspective. MAIN was used to compare narrative abilities of monolingual speakers of different ages, for preschool age children, early school age children and adults. Scores were significantly different among all three groups $(\mathrm{p}<.01)$ (Figure 3).

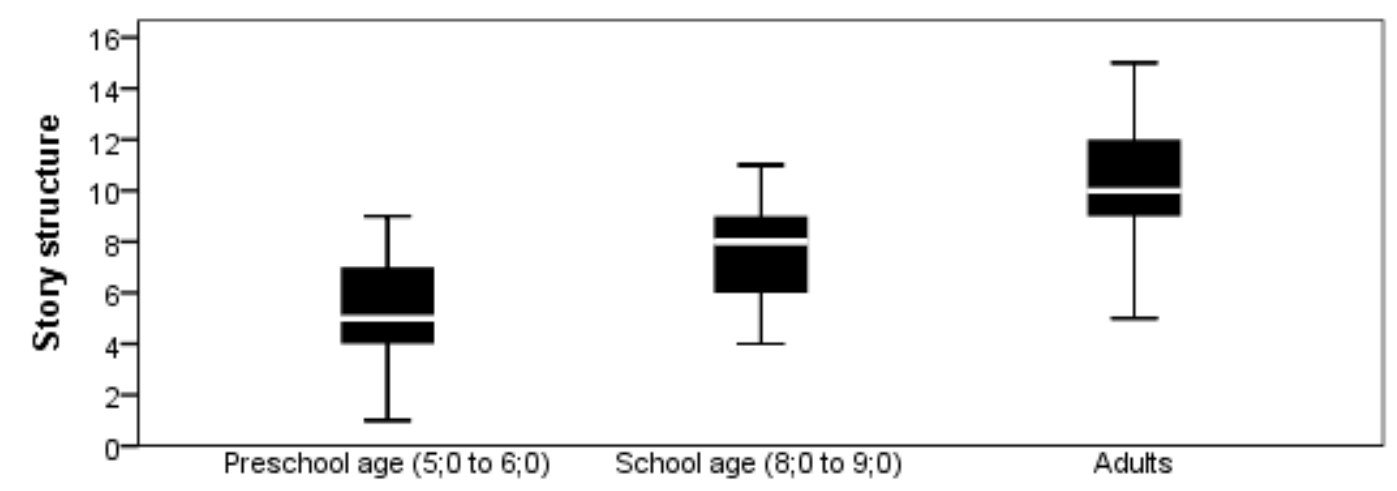

Figure 3: Story structure (macrostructure) results for Croatian preschool children $(\mathrm{N}=50)$, school children $(\mathrm{N}=55)$ and adults $(\mathrm{N}=60)$.

\subsection{Studies in which the Croatian version of MAIN is the primary assessment tool}

The first study conducted with the Croatian version of MAIN compared the story structure in the narratives generated by 20 typically developing monolingual children with those of 20 monolingual children with developmental language disorder (Kuvač Kraljević, Hržica \& Vdović Gorup, 2020). Children, whose age ranged from 5;6 to 7;6, were asked to produce two narratives, one elicited by a sequence of six pictures ("telling" - either Baby Goats of Baby Birds) and the other elicited by an oral model of the story and the sequence of six pictures ("retelling" - either Cat or Dog). The typically-developing children performed significantly better than their counterparts with language disorder on the MAIN story structure in both narrative tasks. The typically-developing children performed similarly when telling and retelling, while those with developmental language disorder were significantly better at retelling than telling.

The second study investigated the ability of monolingual children to refer to story characters in narratives elicited using the Croatian version of MAIN (Gabaj \& Kuvač Kraljević, 2019). There were three groups of participants: 23 preschool children, 23 early school-age children and 23 adults. Children differed from adults in reintroduction and in maintenance. When reintroducing a character, they use NPs less often than adults, but no difference was found between two groups of children. When maintaining characters, preschool children used 
pronouns significantly less often than adults, and both groups of children used null anaphors significantly less often than adults. Preschool children were the group that least often referred adequately to characters. These results point to age-related developmental changes in character referencing.

A third study explored the referential forms chosen by 50 monolingual children $(6 ; 0$ 6;11) and 50 adults in two MAIN stories, "Baby Birds" and "Baby Goats" (Hržica \& Kuvač Kraljević, in press). The participants had to construct a "Baby Goats" narrative based on pictures showing characters of different grammatical gender, and a "Baby Birds" narrative based on pictures in which all characters had the same grammatical gender. The adults produced more referential expressions in their narratives, while both groups used lexical NPs (nominals) more often to introduce and reintroduce characters than in maintenance. When maintaining characters, children and adults used more nouns and fewer pronouns for the "Baby Birds" story, while the converse was true for the "Baby Goats" story. These results suggest that nominals are used more often to refer to same gender characters in multi-character stories, which supports the discourse-oriented approach.

A fourth study examined whether vocabulary diversity measures can be used across languages when assessing bilingual preschool children. The research examined 30 sequential bilingual children ( 5 - 7 years old) speaking Croatian and Italian, together with age-matched monolingual peers in each language (Hržica \& Roch, in press). MAIN was used to elicit narrative samples and calculate lexical diversity measures, which were assessed for their agreement with performance on the Peabody Picture Vocabulary Test (PPVT). While the two lexical diversity measures type-token ratio (TTR) and the measure known as Maas index, proposed by Maas (1972) did not differentiate between bilinguals and monolinguals, several others did: total number of words, number of different words, D, moving average type-token ratio and hypergeometric diversity of $\mathrm{D}$. These last five measures predicted PPVT results for monolinguals, and three (total number of words, number of different words, D) predicted PPVT results for bilinguals. These results suggest that language diversity measures can reliably measure bilinguals' vocabulary knowledge and can align with PPVT results in languages other than English.

Finally, a fifth study involving the same sample as the fourth one examined to what extent receptive vocabulary and receptive grammar (sentence comprehension) can predict narrative comprehension skills in both languages of bilingual speakers (5-7 years old) speaking Croatian and Italian (Roch \& Hržica, in press). Regression analyses showed that sentence comprehension contributed significantly to narrative comprehension in both L1 and L2, while receptive vocabulary contributed significantly only in $\mathrm{L} 1$.

\section{Conclusion}

As has been shown in the summary of previous research presented above (Section 3), the Croatian adaptation of MAIN has proven to be a valuable tool for assessing narrative abilities of Croatian speakers from preschool age to adults. Participants enjoy the tasks because the 
stories have interesting content and children can easily relate to characters. Although the stories are presented on only 6 pictures, they show rich and dynamic events which is very motivating for children. The pictures that are appealing and colourful additionally encourage production. The tests are easy to administer and scoring is transparent. These features make MAIN attractive and practical for micro- and macro-level analyses. To conclude, MAIN has shown to be a useful research tool and we hope this new version will serve us and other researchers and clinicians to evaluate narrative skills of children and to help identify children with atypical development.

\section{References}

Altman, C., Armon-Lotem, S., Fichman, S., \& Walters, J. (2016). Macrostructure, microstructure, and mental state terms in the narratives of English-Hebrew bilingual preschool children with and without specific language impairment. Applied Psycholinguistics, 37(1), 165-193.

Arapović, D., Grobler, M., \& Jakubin, M. (2010). Narativni diskurs predškolske djece s posebnim jezičnim teškoćama. Logopedija, 2(1), 1-6.

Bishop, D. V., Kuvač Kraljević, J., Hržica, G., Kovačević. M., \& Kologranić Belić, L. (2014). Test razumijevanje gramatike (TROG-2:HR). Zagreb/Jastrebarsko: Naklada Slap.

Boerma, T., Leseman, P., Timmermeister, M., Wijnen, F. and Blom, E. (2016) Narrative abilities of monolingual and bilingual children with and without language impairment: implications for clinical practice. International Journal of Language \& Communication Disorders, 51(6), 626-638.

Bohnacker, U. (2016). Tell me a story in English or Swedish: Narrative production and comprehension in bilingual preschoolers and first graders. Applied Psycholinguistics, 37(1), 19-48.

Botting, N. (2002). Narrative as a tool for the assessment of linguistic and pragmatic impairments. Child Language Teaching and Therapy, 18(1), 1-21.

Borsa, J. C., Damásio, B. F., \& Bandeira, D. R. (2012). Cross-cultural adaptation and validation of psychological instruments: some considerations. Paidéia (Ribeirão Preto), 22(53), 423-432.

Edwards, S., Letts, C., Sinka, I., Kuvač Kraljević, J., Kologranić, Belić, L., Hržica, G., \& Kovačević. M. (2019). Nove Reynell razvojne jezične ljestvice (NRDLS-HR). Zagreb/Jastrebarsko: Naklada Slap

Gabaj, M., \& Kuvač Kraljević, J. (2019). Označavanje likova u dječjem pripovjednom diskursu. Logopedija, 9(2), 40-49.

Gagarina, N., Klop, D., Kunnari, S., Tantele, K., Välimaa, T., Balčiūnienè, I., Bohacker, U., \& Walters, J. (2012). MAIN: Multilingual Assessment Instrument for Narratives. ZAS Papers in Linguistics, 56.

Gagarina, N., Klop, D., Kunnari, S., Tantele, K., Välimaa, T., Balčiūnienė, I., Bohnacker, U., \& Walters, J. (2015). Assessment of Narrative Abilities in Bilingual Children. In S. Armon-Lotem, J. de Jong, \& N. Meir (Eds.), Assessing multilingual: children disentangling bilingualism from language impairment (pp. 243-269). Bristol: Multilingual Matters.

Gagarina, N., Klop, D., Kunnari, S., Tantele, K., Välimaa, T., Bohnacker, U. \& Walters, J. (2019). MAIN: Multilingual Assessment Instrument for Narratives - Revised. ZAS Papers in Linguistics, 63. 
Gagarina, N., Klop, D., Tsimpli, I., \& Walters, J. (2016). Narrative abilities in bilingual children. Applied Psycholinguistics, 37(1), 11-17.

Hržica, G., \& Lice, K. (2012). Morfološke pogreške u uzorcima govornog jezika. Hrvatska revija za rehabilitacijska istraživanja, 49(1), 65-77.

Hržica, G., \& Kuvač Kraljević, J. (in press). Referential choice in ambiguous narrative discourse. First Language.

Hržica, G., \& Roch, M. (in press). Lexical diversity in bilingual speakers of Croatian and Italian. In: ArmonLotem, Sharon \& Grohmann, Kleanthes (ed.), LITMUS in Action: Cross comparison studies across Europe. Amsterdam: John Benjamins.

Hržica, G., Košutar, S., \& Kramarić, M. (2019). Rječnička raznolikost pisanih tekstova osoba s razvojnim jezičnim poremećajem. Hrvatska revija za rehabilitacijska istraživanja, 55(2), 14-30.

Kelić, M., Hržica, G., \& Kuvač Kraljević, J. (2012). Mjere jezičnog razvoja kao klinički pokazatelji posebnih jezičnih teškoća. Hrvatska revija za rehabilitacijska istraživanja, 48(2), 23-40.

Köpke, B., \& Genevska-Hanke, D. (2018). First Language Attrition and Dominance: Same Same or Different? Frontiers in Psychology, 9, 1963.

Kuvač Kraljević, J., Hržica, G., \& Vdović Gorup, I. (2020) A comparative macrostructural analysis of narrative discourse in children with typical language development and children with developmental language disorder. Društvena istraživanja.

Kuvač, J. (2004). Jezik i spoznaja u ranom dječjem pripovijedanju. Magistarski rad. Zagreb: Filozofski fakultet.

Lindgren, J. (2019). Comprehension and production of narrative macrostructure in Swedish: A longitudinal study from age 4 to 7 . First Language, 39(4), 412-432.

Maas, H.D. (1972). Zusammenhang zwischen Wortschatzumfang und Länge eines Textes. Zeitschrift für Literaturwissenschaft und Linguistik, 8, 73-79.

Roch, M., \& Hržica, G. (in press). Narrative comprehension by Croatian-Italian bilingual children 5-7 years old: the role of receptive vocabulary and sentence comprehension. In: U. Bohnacker \& N. Gagarina (Eds.), Developing narrative comprehension: Multilingual Assessment Instrument for Narratives. Amsterdam: John Benjamins.

Trtanj, I., \& Kuvač Kraljević, J. (2017). Jezična i govorna obilježja dječjega pripovjednog diskursa: analiza na mikrostrukturnoj razini. Govor: časopis za fonetiku, 34(1), 53-69.

Trtanj, I. (2019). Organizacija pripovjednoga diskursa: anafora i kohezija u dječjem pripovijedanju. Jezikoslovlje, 20(3), 583-601.

Tsimpli, I. M., Peristeri, E and Andreou, M. (2016) Narrative production in monolingual and bilingual children with specific language impairment. Applied Psycholinguistics, 37, 195-216. 